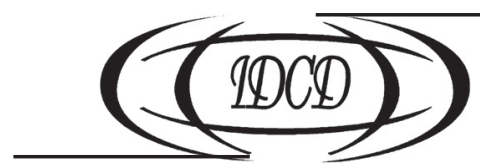

doi : $10.15407 /$ dse2016.01.080

УДК 314.47 (477)

\title{
Н.М. ЛЕВЧУК
}

д-р екон. наук, старш. наук. співроб., голов. наук. співроб.

Інститут демографії та соціальних досліджень

ім. М.В. Птухи НАН України

01032, Київ, бул. Т. Шевченка, 60

E-mail: levchuk.nata@gmail.com

\section{КАЛЕНДАРНА Й КОГОРТНА ТРИВАЛІСТЬ ЖИТТЯ В УКРАЇНІ: ОСОБЛИВОСТІ ДИНАМІКИ У ДОВГОТРИВАЛІЙ РЕТРОСПЕКТИВІ}

Виконано порівняльний аналіз динаміки календарної та когортної тривалості життя в Україні в історичній ретроспективі: за період 1850-2013 рр. та для когорт 1850-1923 рр. народження. Дослідження довготривалих динамічних рядів параметрів дожиття населення виявило, що на відміну від розвинених країн тривалість життя реальних поколінь в Україні суттєво відстає від тривалості жсиття умовних поколінь та існує дивергенція утрендах показників чоловіків іжінок. Ужінок як когортна, так ікалендарна тривалість життя зростали; при цьому приріст тривалості життя реальних поколінь був меншим, ніж приріст тривалості життя умовних поколінь. На противагу жінкам, у чоловіків тривалість життя для майже 70 реальних поколінь перебувала на однаково низькому рівні: в середньому близько 30 років. Когортна тривалість життя чоловіків помітно нижча за календарну. Найбільш неблагополучними є когорти, народжені у 1917-1921 рр., що мають найкоротшу тривалість життя. Зокрема, тривалість життя чоловіків 1917-го року народження становить лище 17,9 року. Доведено, що стагнація та відсутність прогресу у показниках дожиття чоловіків пов'язана зі значними втратами років життя, насамперед у віці 15-49 років, через низку послідовних соціальних катастроф, що відбулися в Україні у першій половині ХХ століття. Обгрунтовано висновок про те, що відмінності у тривалості життя між Україною та розвиненими країнами для реальних поколінь є більшими, ніж для умовних поколінь.

Ключові слова: смертність, когорта, умовні та реальні покоління, календарна й когортна тривалість життя, населення, Україна.

\section{Н.М. Левчук}

д-р экон. наук, глав. науч. сотруд.

Институт демографии и социальных исследований

им. М.В. Птухи НАН Украины

01032, Киев, бул. Т. Шевченка, 60

E-mail: levchuk.nata@gmail.com

\section{КАЛЕНДАРНАЯ И КОГОРТНАЯ ПРОДОЛЖИТЕЛЬНОСТЬ ЖИЗНИ В УКРАИНЕ: ОСОБЕННОСТИ ДИНАМИКИ В ДОЛГОСРОЧНОЙ РЕТРОСПЕКТИВЕ}

Проведен сравнительный анализ динамики календарной и когортной продолжстельности жизни в Украине в исторической ретроспективе: за период с 1850 по 2013 гг. и для когорт 1850-2013 гг.

(С ЛЕВЧУК Н.М., 2016 
рождения. Анализ динамических рядов параметров дожития населения показал, что в отличие от развитых стран продолжительность жизни реальных поколений в Украине существенно отстает от продолжительности жизни условных поколений и существует дивергенция в трендах показателей мужчин и женщин. У женщин как когортная, так и календарная продолжительность жизни росли; при этом прирост продолжительности жизни реальных поколений был меньше, чем прирост продолжительности жизни условных поколений. В противоположность женщинам, у мужчин продолжительность жизни для почти 70 реальных поколений находилась на одинаково низком уровне: в среднем около 30 лет. Когортная продолжительность жизни мужчин заметно ниже календарной. Наиболее неблагополучны когорты, рожденные в 1917-1921 г2., имеющие самую низкую продолжительность жизни. В частности, продолжительность жизни у мужчин 1917-го года рождения составляет лишь 17,9года. Доказано, что стагнация и отсутствие прогресса в показателях дожития мужчин связаны со значительными потерями лет жизни, прежде всего в возрасте 15-49 лет, из-за ряда последовательных социальных катастроф, которые произошли в Украине в первой половине ХХ века. Обоснован вывод о том, что различия в продолжительности жизни между Украиной и развитыми странами для реальных поколений являются более значительными, чем для условных поколений.

Ключевые слова: смертность, когорта, условные и реальные поколения, календарная и когортная продолжительность жизни, население, Украина.

\author{
N.M. Levchuk \\ Dr. (Economics), Senior Researcher, \\ Ptoukha Institute for Demography and Social Studies \\ of the National Academy of Sciences of Ukraine \\ 01032, Kyiv, Taras Shevchenko Blvd., 60 \\ E-mail: levchuk.nata@gmail.com
}

\title{
LONG-TERM TRENDS IN PERIOD AND COHORT LIFE EXPECTANCIES IN UKRAINE
}

The aim of this study is to investigate and to compare long-term trends of the period and cohort life expectancies in Ukraine for the period from 1850 to 2013 and for the cohorts born from 1850 to 1923. We found that the cohort life expectancy in Ukraine lagged behind the period life expectancy. There is also a divergence in the dynamics of cohort and period life expectancies between men and women. For women, both period and cohort life expectancies have increased over time and across cohorts although cohort life expectancy increased more slowly than its period counterpart. However, the results indicated a long-term stagnation in male cohort longevity. The cohort life expectancy over 70 years of successive birth cohorts of males in Ukraine was fairly stable at a very low level: around 30 years. Male cohort life expectancy is substantially lower than corresponding period life expectancy. The cohorts born in 1917-1921 were the most disadvantaged in terms of survival and had the lowest life span. In particular, the cohort life expectancy for men born in 1917 was just 17.9 year. This study revealed that stagnation in male cohort life expectancy was most likely associated with the reduction of the cohort life time at the age from 15 to 49 due to a series of catastrophes that took place during the first half of the 20th century. We conclude that the differences between Ukraine and the Western countries are more pronounced for cohort life expectancy than for period life expectancy.

Key words: mortality, cohort, real and synthetic cohorts, period and cohort life expectancies, population, Ukraine.

Постановка проблеми. Більшість досліджень демографічної історії України, зокрема щодо смертності населення й тривалості життя, представлені аналізом періоду другої половини XX - початку XXI століття, тоді як вивчення смертності населення в глибокій історичній ретроспективі досі не проводилося. При цьому вчені акцентують увагу на важливих суспільних факторах і подіях, що відбулися у певний календарний період, і відповідній динаміці параметрів дожиття населення України, обчислених за методом умовного покоління. Разом з тим, про особливості дожиття реальних поколінь українського населення відомо зовсім мало. Тим часом, неврахування когортних ефектів у вивченні демографічних трендів може призвести до спотворення висно- 
вків. Так, часто передбачається, що підвищення або зниження смертності населення за певний період відбулося рівномірно поміж різних когорт населення. Насправді, представники різних поколінь можуть по-різному реагувати на ті чи інші позитивні або негативні суспільні зрушення. Порівняльний аналіз довготривалих трендів у календарній та когортній тривалості життя є особливо актуальним, оскільки наша країна зазнала руйнівного впливу багатьох соціальних катастроф першої половини ХХ століття.

Аналіз останніх досліджень та публікацій. Вивчення динаміки календарної тривалості життя й особливостей режиму смертності населення України перебувають у центрі уваги багатьох сучасних українських і зарубіжних науковців. Значний внесок у розробку цього напряму демографічних досліджень в Україні здійснили такі вчені Е.М. Лібанова (Е.M. Libanova), С.I. Пирожков (S.I. Pyrozhkov), C.A. Понякіна (S.A. Ponyakina), Н.О. Рингач (N.O. Ryngach), О.П. Рудницький (O.P. Rudnytskyi), A.I. Стефановський (А.I. Stefanovskyi), П.Є. Шевчук (Р.E. Shevchuk). Серед зарубіжних вчених, які досліджують різні аспекти даної тематики, варто назвати Є. М. Андрєєва (E.M. Andreev), Ж. Валлєна (J. Vallen), А.Г. Вишневського (A.G. Vishnevskiy), Ф. Меслє (F. Mesle), Т.Г. Харькову (T.G. Kharkova), В.М. Школьнікова (V.M. Shkolnikov).

Когортні дослідження смертності населення України практично відсутні через брак відповідних статистичних даних, зокрема, довготривалих рядів демографічних показників. Нам відомо лише одне дослідження міжпоколінних аспектів у смертності населення України, проведене В.М. Школьніковим за допомогою АРС-аналізу [1]. Однак дану модель було побудовано лише для населення віком 5-65 років та періоду 1965-2000 рр., й дослідження не виявило чітких когортних ефектів у формуванні динаміки смертності населення.

Мета роботи полягає у проведенні порівняльного аналізу довготривалих трендів календарної й когортної тривалості життя в Україні та з'ясуванні особливостей їх динаміки за віком і статтю від середини XIX до початку XXI століття.

Дані. Базою дослідження слугували таблиці смертності й тривалості життя в Україні для умовних і реальних поколінь. Зокрема, щорічні таблиці смертності для умовних поколінь України за період 1850-2013 роки (в сучасних політико-адміністративних межах), побудовані на основі реконструйованих динамічних рядів померлих, народжених та чисельності населення за статтю та віком. Когортні таблиці смертності й тривалості життя в Україні розраховані для поколінь 1850-1923 рр. народження за однорічними віковими групами, при цьому для когорт 1850-1913 рр. народження тривалість життя обчислена повністю за наявними даними, оскільки їі представники вже досягли віку 100 років. Для когорт 1914-1923 рр. народження, які дожили до 85 років, але ще не досягли 100 років, тобто неповних когорт, була здійснена екстраполяція коефіцієнтів смертності в старших вікових групах за формулою Гомпертца. Когортні таблиці смертності розраховані згідно з методичним протоколом, розробленим у рамках дослідницького проекту Human Mortality Database (University of California, Berkeley and Max Planck Institute for Demographic Research).

Реконструкція демографічної динаміки України та побудова таблиць смертності для умовних і реальних поколінь виконані науковими співробітниками Інституту демографії та соціальних досліджень ім. М.В. Птухи НАН Ураїни О.П. Рудницьким, П.Є. Шевчуком і А.Б. Ковбасюк.

З метою виявлення особливостей довгострокової динаміки параметрів дожиття в Україні для порівняння була обрана Швеція, оскільки вона має власні демографічні дані високої якості за досить тривалий період. Ця країна досягла значного прогресу 
в показниках дожиття населення і нині знаходиться в авангарді країн світу за рівнем тривалості життя. Для Швеції були використані таблиці смертності із Human Mortality Database за період 1850-2011 та для когорт 1850-1920 pр. народження.

Виклад основного матеріалу. Очікувана тривалість життя при народженні в певний календарний період характеризує тривалість життя умовного покоління, тобто середнє число років, яке проживуть представники цієї синтетичної когорти за умови збереження повікової смертності протягом їх життя. Фактично, це характеристика рівня смертності конкретного календарного періоду, тоді як когортна тривалість життя відображає реальний рівень дожиття певної сукупності народжених, себто реального покоління [2]. Періодна або календарна тривалість життя може відображати результат тривалих змін у поведінці населення, але не враховує досвід реальних когорт.

Концепт когорти або покоління є дуже важливим у дослідженнях демографічних процесів, у першу чергу з точки зору виявлення впливу певних подій минулого на сучасну поведінку індивідів. Когортою найчастіше називають представників одного року (періоду) народження. Це група осіб, які зазнали однакового впливу тих чи інших важливих суспільно-історичних подій: народилися і виросли в подібних історичних умовах, подібному історичному контексті (війна, голод тощо). Безперечно, умови життя і обставини є індивідуальними, але, незважаючи на відмінності життєвого шляху кожного індивіда, вплив факторів історичного минулого на представників однієї когорти залишається спільним для них протягом їхнього життя. Вплив цих факторів може призвести до підвищення або зниження повікового ризику смерті протягом подальшого життя.

На рис. 1 показана динаміка тривалості життя в Україні та Швеції за період 1850-2011/2013 рр. і для поколінь 1850-1920/1923 років народження. Фактично, упродовж останніх 160 років у Швеції спостерігався добре виражений висхідний тренд у тривалості життя, за винятком періоду між 1857 і 1869 роками (епідемії скарлатини й дифтерії), Першої Світової війни та періоду стагнації у 1950-1960-х роках. У 1850 р. очікувана тривалість життя при народженні у Швеції становила 42,1 року серед чоловіків і 47,3 серед жінок. Упродовж 1850-1900 pp. ïi приріст становив 8,7 року для чоловіків і 6,4 для жінок.

У цій країні, так само як в інших західноєвропейських суспільствах, відбулися значні економічні й соціальні зрушення, і демографічний перехід до низької народжуваності та смертності став невід'ємною частиною соціально-економічних трансформацій. Спочатку відбулося суттєве зниження дитячої смертності та смертності немовлят; смертність дорослого населення також знижувалась, хоча й повільніше [3]. У другій половині ХХ століття внаслідок так званої кардіоваскулярної революції, під час якої було реалізовано широкомасштабну стратегію по зменшенню поширення факторів ризику серцево-судинних хвороб, профілактиці та ефективному лікуванню багатьох неінфекційних захворювань, удалося також значно знизити рівень смертності серед дорослих. Як наслідок, очікувана тривалість життя шведів за період 1970-2010 рр. виросла на 7,3, шведок - на 6,3 року, і у 2011 р. становила 79,8 і 83,7 року для чоловіків та жінок відповідно.

В Україні у 1850 р. тривалість життя становила 27,3 року у чоловіків та 27,8 у жінок. Тоді час Україна відставала від Швеції за показниками тривалості життя в середньому на 15 років у чоловіків та 19 років у жінок. Основною причиною такого відставання був дуже високий рівень смертності немовлят. Процес зниження смертності населення, що відбувався в європейських країнах упродовж першої половини ХХ століття, в Україні був порушений низкою соціальних катастроф, які відбувались 



Рис. 1. Середня тривалість життя умовних і реальних поколінь в Україні та Швеції: період 18502011/2013 та когорти 1850-1920/1923 років народження

Джерело: для України - дані Інституту демографії та соціальних досліджень ім. М.В. Птухи НАН України за період 1850-2013 та когорти 1850-1923 рр.; для Швеції - дані Human Mortality Database за період 1850-2011 та когорти 1850-1920 pp.

одна за одною, не залишаючи часу на відновлення демографічного потенціалу і надолуження втраченого. Згідно з оцінкою О. Гладуна, за умови відсутності цих та інших кризових подій чисельність населення України на початку 1991 р. могла б становити 87,2 млн осіб замість реальних 51,9 млн [4]. Значні демографічні втрати, яких зазнала Україна, призвели до того, що розрив із Швецією у показниках дожиття населення не лише не скоротився, а навіть збільшився (у чоловіків). У 1930 р. чоловіки в Україні мали шанси прожити на 19,6 року, а жінки - на 17,7 року менше, ніж у Швеції. За результатами проведених досліджень, прямі втрати України у Першій Світовій війні становлять 2,8 млн осіб, Другій світовій війні - 7,9 млн, внаслідок Голодомору 1932-1934 pp. - 3,9 млн [4, 5]. Відповідно, тривалість життя в Україні 
у кризові періоди знижувалась надзвичайно - 6,8 року у чоловіків та 11,1 у жінок у 1933 році; 8,6 та 17,7 у 1942 році для чоловіків та жінок відповідно.

Ситуація значно поліпшилась у перші десятиліття повоєнного періоду, коли у середині 1960-х рр. тривалість життя в Україні була на рівні розвинутих європейських країн і відставала від показників Швеції лише на 1,5-3 роки. Проте упродовж наступних десятиліть Україна не лише не зробила відчутного поступу, але й втратила цінні надбання минулого і нині значно поступається розвиненим європейським країнам за показниками життєзбереження населення. Зокрема, у 2013 р. очікувана тривалість життя при народженні становила в Україні 66,3 року серед чоловіків і 76,2 серед жінок. Розрив з відповідними показниками Швеції та інших розвинутих країн становить 13-14 років для чоловіків і 8-9 років для жінок.

Основною причиною такого регресу стало підвищення смертності у трудоактивному віці, насамперед серед чоловіків. Після успішної боротьби з інфекційними хворобами в Україні, як і в інших республіках колишнього СРСР, не відбулося так званої другої епідеміологічної революції, наслідком якої на заході стало встановлення контролю над неінфекційними захворюваннями і витіснення смертей від них у старші вікові групи [6]. Ознакою так званого «незавершеного санітарного переходу» в Україні та інших республіках колишнього СРСР є збереження високого рівня смертності від зовнішніх дій та низький вік смерті від більшості класів причин смерті, насамперед від хвороб системи кровообігу.

Розрив у календарній тривалості життя між чоловіками й жінками в Україні усередині XIX - на початку минулого сторіччя був одним з найменших у Свропі. Він коливався у межах від 0,5 до 1 року. Фактично феномен чоловічої надсмертності, яскраво виражений в Україні у сучасний період, почав формуватись після Першої світової війни. Пікові значення чоловічої надсмертності спостерігались у роки найтяжчих соціальних катастроф і воєн через втрати чоловіків у бойових діях. У мирні часи статеві диспропорції у показниках дожиття почали значно збільшуватись після Другої світової війни. Якщо в 1940 р. в Україні очікувана тривалість життя при народженні у чоловіків була на 4,4 року нижча, ніж у жінок, то у 1960 р. - на 6 років, а у 2000 р. - на 11,4. Аналіз показників календарної тривалості життя чоловіків і жінок показує, що розрив між ними посилювався у періоди зниження тривалості життя і скорочувався у періоди їі підвищення.

Рис. 1 демонструє також виразну позитивну динаміку не лише календарної, а й когортної тривалості життя в Швеції. Когортні показники вимірюють час життя, прожитий реальними поколіннями. У Швеції для чоловіків, народжених в 1850 р., він становив в середньому 44,3 року, а для народжених в 1920 р. - 65,7, тобто тривалість життя між цими когортами зросла на 21,4. В Україні чоловіки, що народились у 1850 і 1920 рр., прожили в середньому 29,1 року і 25,4 року відповідно, тобто тривалість життя не тільки не підвищилася, а зменшилася на 3,7 року поміж цими поколіннями. Якщо у Швеції кожне послідовне покоління чоловіків отримувало певний приріст років життя, то в Україні тривалість життя майже 70-ти поколінь чоловіків коливалася на рівні близько 30 років. Як наслідок, розрив у показниках когортної тривалості життя чоловіків між країнами значно збільшився: для поколінь 1850-го року народження він становив 15,2 року, для поколінь 1910-го року народження - 31,9 року, а для тих, хто народився в 1920 р., розрив між Україною та Швецією досягає 40,3 року.

Такі величезні розбіжності пов’язані, насамперед, з тим, що населення України зазнало руйнівного впливу численних екстраординарних подій і породжених ними демографічних катастроф, які не просто коригували траєкторію демографічного 
розвитку, а докорінно змінили демографічну історію багатьох поколінь українського населення. Життєдіяльність населення відбувалася в умовах довготривалого кризового періоду, коли кризові події слідували одна за одною: три війни, три періоди голоду, неодноразові спалахи епідемій, масові депортації і насильницькі переміщення населення. Тому потенційні успіхи в зниженні смертності чоловіків зводилися нанівець трагічними подіями і масовими людськими втратами, які відкидали країну на десятиліття назад.

Покоління українських чоловіків, починаючи з 1850 і до 1910-го року народження, мають однаково вкрай низьку тривалість життя. У найгіршому становищі опинилися когорти народжених у 1917-1921 роках, стан здоров'я і життєві сили яких були підірвані вже з раннього дитинства і які понесли значні втрати в подальші після народження десятиліття. Тривалість життя цих поколінь є найнижчою: у чоловіків 1917 року народження вона становить лише 17,9 року.

Ще однією характерною особливістю динаміки когортної тривалості життя в Україні є дивергенція і певна асиметричність трендів у чоловіків та жінок. Якщо у Швеції всі зміни в показниках тривалості життя за статтю відбуваються синхронно і відрізняється лише рівень смертності, то в Україні висхідний тренд простежується тільки у жінок, при цьому він виражений значно слабше, ніж у Швеції. Починаючи з поколінь, що народилися в середині 1870-х рр., тривалість життя зростає в обох країнах. Однак, у Швеції жінки, які народилися в 1920 р., мали шанси прожити на 23,1 року більше, ніж ті, хто народився в 1875 році, тоді як в Україні приріст тривалості життя між цими поколіннями склав лише 9,2 року. Відставання України від Швеції за рівнем дожиття серед жінок значно менше, ніж серед чоловіків, але цей розрив мав чітку тенденцію до збільшення: від 17,3 року для жінок 1850 народження до 25,4 року у жінок 1910 народження і до 29,4 року для народжених у 1920 році.

Історія дожиття реальних поколінь показує, що коли смертність була високою і відносно стабільною, когортні й календарні показники були досить подібними, тобто смертність умовного покоління досить точно відображала смертність реального покоління [7].

Коли смертність починає змінюватись, когортна тривалість життя може бути нижчою або вищою, ніж календарна, залежно від напряму зміни. Зниження показників смертності протягом певного календарного періоду сприятливо впливає на показники дожиття саме реального покоління. Школьніков В.М. та співавтори показали, що за умови падіння смертності когортна тривалість життя підвищується швидше, ніж календарна [8]. На рис. 1 видно, що в Швеції на тлі вираженого висхідного тренду календарні показники тривалості життя чоловіків і жінок були нижчими за очікувану тривалість життя народжених у відповідному році. Ця різниця збільшилась від 2,2 року в 1850 до 8,2 у 1920 році для чоловіків і від одного року до 12,6 року для жінок.

В Україні перевищення когортних показників над періодними спостерігалося головним чином для жінок. Так, тривалість життя жінок 1850 -го року народження становила 30,7 року, тоді як очікувана тривалість життя у цей календарний рік - 27,8 року. Тривалість життя для жінок, народжених у 1923 р., становила 48,1 року, а відповідний календарний показник - 44,6. Іншими словами, жінки, народжені в 1923 р., за умови збереження тогочасного режиму вимирання протягом їхнього подальшого життя, мали шанс прожити в середньому 44,6 року, але реально прожили на 3,5 року більше. Цей виграш отримано в результаті більш сприятливого режиму смертності жінок у подальші роки історії життя цього покоління. 


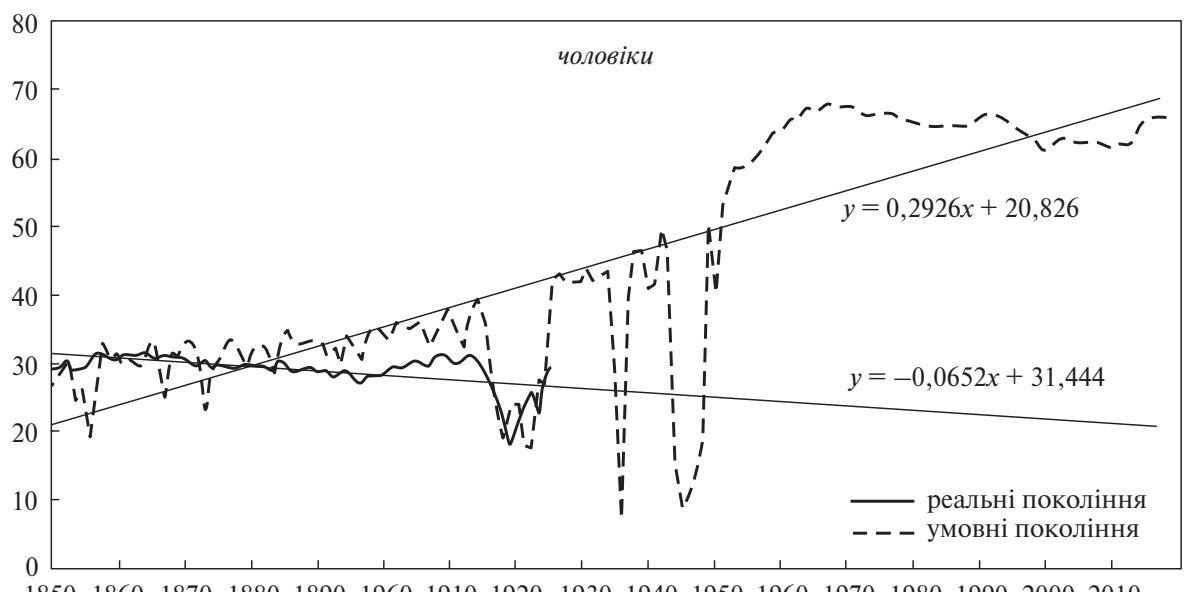

18501860187018801890196019101920193019401950196019701980199020002010

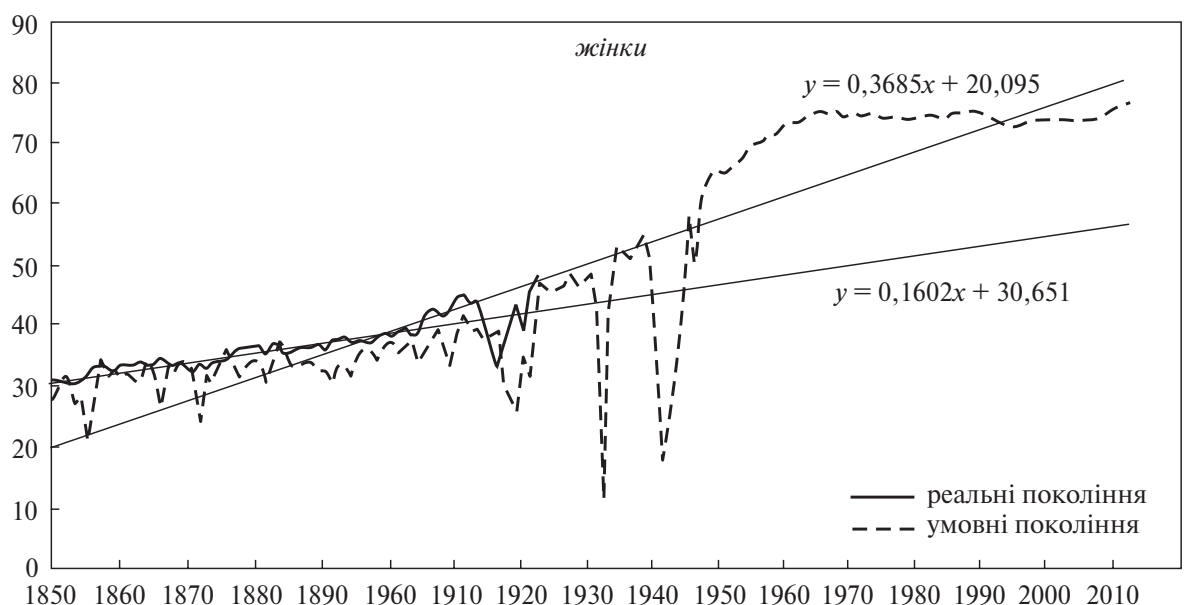

Рис. 2. Середня тривалість життя умовних і реальних поколінь в Україні: період 1850-2013 роки та когорти 1850-1923 років народження

Джерело: дані Інституту демографії та соціальних досліджень ім. М.В. Птухи НАН України.

У чоловіків ситуація інша. Хоча когортні показники в окремі періоди були вищими, ніж періодні, загалом тривалість життя реальних поколінь чоловіків значно відставала від відповідних показників календарного періоду. Протягом 1850-1880 pp. показники когортної та календарної тривалості життя були досить близькими за своїми значеннями. Виняток становили окремі роки, що супроводжувались епідеміями і різким підйомом смертності, коли когортна тривалість життя чоловіків перевищувала календарну. 3 1890-х рр. спостерігалась чітка тенденція до збільшення розриву між когортними і календарними показниками за рахунок підвищення календарної та стагнації когортної тривалості життя. Так, в 1900 р. очікувана тривалість життя чоловіків становила 35,8 року, але покоління народжених протягом того року прожило в середньому лише 29,5 року.

На рис. 2 побудовано лінійні тренди, що досить наближено апроксимують відповідні часові ряди показників тривалості життя. У цьому випадку лінія лінійного 
(а не поліноміального) тренду була використана як більш зручний додатковий інструмент задля того, щоби проілюструвати, з якою швидкістю відбувалось падіння або приріст тривалості життя у минулому. Як бачимо, тривалість життя чоловіків в Україні за період 1850-2013 рр. збільшувалася в середньому на 0,29 року за календарний рік, тоді як когортна тривалість життя для чоловіків 1850-1923 років народження - зменшувалася в середньому на 0,07 року (рис. 2). Це пояснюється, як вже вказано, значними флуктуаціями у смертності чоловіків і їх величезними втратами під час воєн і голоду. На відміну від чоловіків у жінок як когортні, так і календарні показники зростали, проте приріст тривалості життя реальних поколінь помітно відставав від приросту тривалості життя умовних поколінь. Зокрема, когортна тривалість життя збільшувалася в середньому на 0,16 року, а календарний показник - на 0,37 в середньому за рік.

У табл. 1 подано результати декомпозиції когортної і календарної тривалості життя за віковими інтервалами. Обчислені показники відображають кількість років життя, прожитих у кожному віковому інтервалі. Так, для чоловіків, народжених у 1850 році, тривалість життя становила 29,1 року, з яких у середньому 8,7 року прожито у віці до 15 років; 12,9 року - від 15 до 45; 5,8 року - від 45 до 60 та 1,7 року у віці від 60 до 85 років.

Таблиця 1. Декомпозиція когортної і календарної тривалості життя чоловіків за віковими інтервалами: покоління 1850 і 1923 років народження, період 1850 і 1923, число років життя

\begin{tabular}{|l|c|c|c|}
\hline \multirow{2}{*}{ Віковий інтервал, років } & \multicolumn{3}{|c|}{ Когортна тривалість життя } \\
\cline { 2 - 4 } & $\begin{array}{c}\text { Когорта 1850-го року } \\
\text { народження }\end{array}$ & $\begin{array}{c}\text { Когорта 1923-го року } \\
\text { народження }\end{array}$ & $\begin{array}{c}\text { Різниця } \\
\mathbf{2}-\mathbf{1}\end{array}$ \\
\cline { 2 - 4 } & 1 & 2 & 3 \\
\hline $0-15$ & 8,7 & 10,7 & 2,0 \\
\hline $15-45$ & 12,9 & 11,2 & $-1,7$ \\
\hline $45-60$ & 5,8 & 5,4 & $-0,4$ \\
\hline $60-85$ & 1,7 & 2,4 & 0,7 \\
\hline $85+$ & 0,0 & 0,1 & 0,1 \\
\hline Усього & 29,1 & 29,8 & 0,7 \\
\hline \multirow{2}{*}{} & \multicolumn{2}{|c|}{ Календарна тривалість життя } & Різниця \\
\hline & 8,7 & $\mathbf{1 9 2 3}$ & 2,2 \\
\hline $0-15$ & 12,3 & 10,9 & 6,0 \\
\hline $15-45$ & 4,7 & 18,3 & 4,3 \\
\hline $45-60$ & 1,4 & 9,0 & 2,3 \\
\hline $60-85$ & 0,1 & 3,7 & 0,2 \\
\hline $85+$ & 27,2 & 0,3 & 15,0 \\
\hline Усього & 1,9 & 42,2 & \\
\hline $\begin{array}{l}\text { Різниця між когортною та ка- } \\
\text { лендарною тривалістю життя }\end{array}$ & & $-12,4$ & \\
\hline
\end{tabular}

Джерело: авторські розрахунки за даними Інституту демографії та соціальних досліджень ім. М.В. Птухи НАН України. 
Порівняльний аналіз зміни когортних і періодних показників та часу життя, прожитого у різних вікових інтервалах, свідчить про їх різну динаміку. У чоловіків в 1923 р. порівняно з 1850 р. календарна тривалість життя виросла на 15 років, а когортна - лише на 0,7 року. Це відбулося за рахунок того, що в умовних поколіннях стався помітний приріст років життя на всіх вікових інтервалах і особливо у віці від 15 до 45 років, тоді як у реальних поколіннях приріст років життя у дитячому віці був майже повністю нівельований значними втратами тривалості життя у віці від 15 до 45 років (табл. 1).

У жінок відбувся приріст як когортної, так і календарної тривалості життя. При цьому для когорти 1923 року народження порівняно з когортою 1850 року народження приріст тривалості життя виявився дещо помітнішим (17,3 року), ніж приріст відповідних календарних показників (16,8 року). Це відбулося за рахунок більшого приросту років життя у дитячому й похилому віці (табл. 2).

На рис. 3 зображено динаміку тривалості життя чоловіків і жінок в Україні при досягненні віку 10, 20, 30, 40, 50, 60 років для поколінь 1850-1923 років народження. Тобто, це середнє число років очікуваного життя для осіб, які дожили до певного віку. Як бачимо, зниження когортної тривалості життя у чоловіків відбувалось, насамперед,

Таблиия 2. Декомопозиція когортної та календарної тривалості життя жінок за віковими інтервалами: покоління 1850 і 1923 років народження, період 1850 і 1923

\begin{tabular}{|l|c|c|c|}
\hline \multirow{2}{*}{ Віковий інтервал, років } & \multicolumn{3}{|c|}{ Когортна тривалість життя } \\
\cline { 2 - 4 } & $\begin{array}{c}\text { Когорта 1850-го року } \\
\text { народження }\end{array}$ & $\begin{array}{c}\text { Когорта 1923-го року } \\
\text { народження }\end{array}$ & $\begin{array}{c}\text { Різниця } \\
\mathbf{2}-\mathbf{1}\end{array}$ \\
\cline { 2 - 4 } & 1 & 2 & 3 \\
\hline $0-15$ & 9,2 & 11,4 & 2,2 \\
\hline $15-45$ & 13,5 & 18,2 & 4,7 \\
\hline $45-60$ & 6,0 & 10,9 & 4,9 \\
\hline $60-85$ & 1,9 & 6,9 & 5,0 \\
\hline $85+$ & 0,1 & 0,6 & 0,5 \\
\hline Усього & 30,7 & 48,0 & 17,3 \\
\hline & & Календарна тривалість життя & Різниця \\
\hline & $\mathbf{1 8 5 0}$ & $\mathbf{1 9 2 3}$ & 1,9 \\
\hline $0-15$ & 9,1 & 11,0 & 6,1 \\
\hline $15-45$ & 12,6 & 18,7 & 5,3 \\
\hline $45-60$ & 4,6 & 9,9 & 3,3 \\
\hline $60-85$ & 1,3 & 4,6 & 0,2 \\
\hline $85+$ & 0,1 & 0,3 & 16,8 \\
\hline Усього & 27,7 & 44,5 & \\
\hline Різниця між когортною та ка- & 3,0 & 3,5 & \\
\hline лендарною тривалістю життя & & & \\
\hline
\end{tabular}

Джерело: авторські розрахунки за даними Інституту демографії та соціальних досліджень ім. М.В. Птухи НАН України. 
за рахунок значного скорочення тривалості життя при досягненні 10 і 20 років. Вона знижувалась із кожним послідовним поколінням чоловіків, досягнувши мінімуму для когорт 1917-1921 років народження. Тобто ці покоління чоловіків мали шанси прожити менше, ніж їхні батьки й діди. Зокрема, тривалість життя при досягненні 10-річного віку становила для чоловіків 1860 року народження 45,8 року; 1890 - 38,5 року, а для тих, хто народився у 1917 р. - лише 26,9 року. Зниження смертності після завершення Другої світової війни сприятливо позначилось на показниках дожиття реальних поколінь чоловіків. Так, відбулося підвищення тривалості життя при досягненні 30 років - серед когорт чоловіків 1910-1915 pр. народження, при досягненні 40 років - для когорт 1900-1905 років народження, при досягненні 50 років - для когорт 1890-1900 років народження та при досягненні 60 років - для когорт 1880-1885 років народження. Однак цей період був нетривалим і в подальшому почалася стагнація показників тривалості життя при досягненні 30 років і старше.

Поміж поколінь жінок 1850-1923 років народження показники тривалості життя при досягненні різного віку мали тенденцію до зростання. Проте, для деяких когорт у певному віці зростання припинилось, і це по різному вплинуло на показники їх дожиття.

Фактично, найбільш благополучними виявились найстарші когорти жінок: 1850-1890 років народження, оскільки для них тривалість життя послідовно зростала на різних вікових інтервалах, спостерігався повільний приріст років життя. Для наступних поколінь ситуація змінилась. Для когорт 1890-х років народження характерна стагнація показників тривалості життя; приріст років життя спостерігався лише у старшому віці, при досягненні 50 років.

Для когорт 1900-1915 років народження тривалість життя при народженні виросла за рахунок приросту років життя у 10, 20, 30 та 40 років, але при цьому не відбулося збільшення тривалості життя у 50 і 60 років. Покоління жінок 1917-1921 pp. народження, як і чоловіки, виявились у найгіршому становищі, оскільки вони зазнали втрат років життя у 10 і 20 років, а тривалість життя при досягненні 30 років і старше у них залишилась майже незмінною.
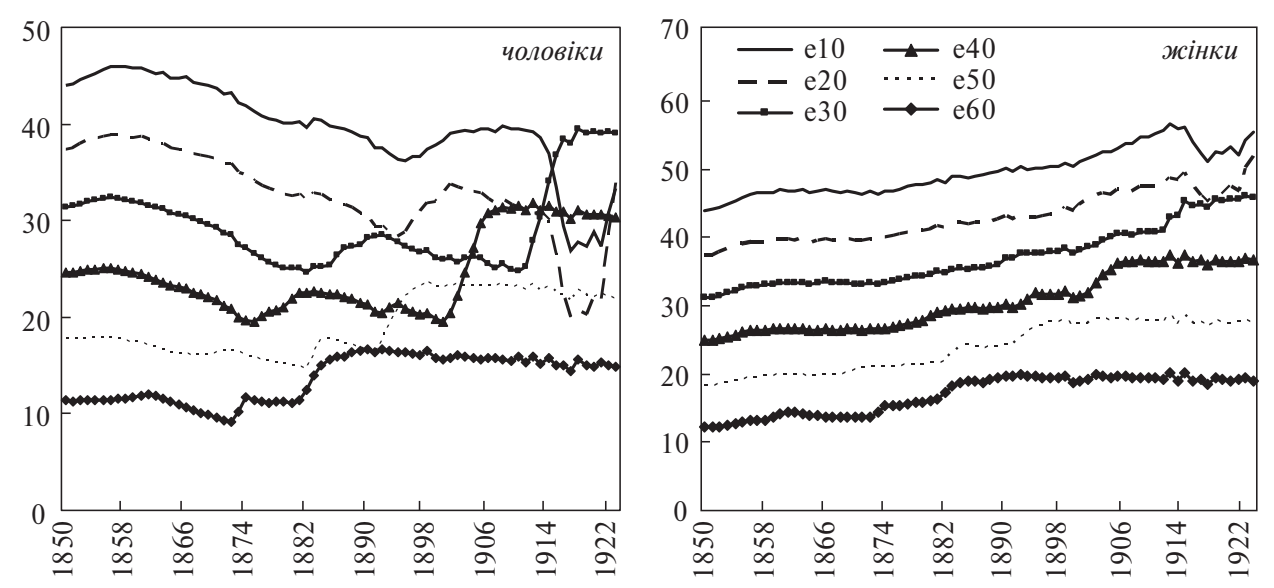

Рис. 3. Тривалість життя реальних поколінь при досягненні 10, 20, 30, 40, 50, 60 років в Україні: когорти 1850-1923 років народження

Джерело: дані Інституту демографії та соціальних досліджень ім. М.В. Птухи НАН України. 
Висновки. Порівняльний аналіз трендів у календарній та когортній тривалості життя в Україні, виконанийний на основі довготривалих динамічних рядів смертності населення, дав змогу встановити суттєвий розрив у рівні тривалості життя умовних і реальних поколінь та дивергенцію календарних і когортних показників чоловіків та жінок.

У розвинутих країнах із вираженим висхідним трендом тривалість життя реальних поколінь для обох статей є вищою за тривалість життя умовних поколінь, тоді як в Україні перевищення когортних показників над календарними спостерігалося лише для жінок. Траєкторії параметрів дожиття населення нашої країни виразно демонструють, наскільки складною і трагічною виявилась історія дожиття багатьох поколінь української людності. Соціальні катастрофи першої половини XX століття різко спотворили природну еволюційну динаміку демографічного розвитку нашої країни. Як наслідок, вона відстає від розвинених країн за рівнем не лише календарної, а й когортної тривалості життя, при цьому відставання реальних поколінь за тривалістю життя є суттєвішим. Зокрема, розрив у показниках когортної тривалості життя чоловіків між Україною та Швецією для поколінь 1850-го року народження становив 15,2 року; для поколінь 1900-го року народження - 27 років, а для тих, хто народився в 1917 р. - 47 років. Відставання за відповідними показниками календарної тривалості життя становило для чоловіків: в 1850 р. - 14,9 року, 1900 - 15 років, $1917-33,6$ року.

Через втрати, спричинені соціальними катастрофами, тривалість життя майже 70-ти реальних поколінь чоловіків в Україні практично не зростала, а найбільш постраждалі, винищені когорти задали початок демографічних хвиль у вигляді наступних малолюдних поколінь їхніх дітей та онуків.

У цьому контексті особливий інтерес становлять подальші дослідження, пов'язані із вивченням довгострокових наслідків соціальних катастроф, зокрема особливостей стану здоров'я і рівня смертності серед когорт, народжених у роки соціальних катастроф (голоду та воєн).

\section{ЛІТЕРАТУРА}

1. Shkolnikov V.M. Chapter 7. Health Crises and Cohort Mortality. // Mortality and causes of death in 20th-century Ukraine. Demographic Research Monographs / Meslé, F., Vallin, J. (Eds.). - Springer, 2012.- P. 109-117.

2. Wilmoth J.R. On the relationship between period and cohort mortality // Demographic Research. 2005. - 13, Article 11. - P. 231-280.

3. Reher D.S. Economic and social implications of the demographic transition. // Demographic transition and its consequences . - Supplement to Vol. 37 of Population and Development Review Ronald D. Lee and David S. Reher (Eds.) - 2011. - P. 11-33.

4. Romaniuk A., Gladun O. Demographic trends in Ukraine: past, present and future // Population and Development Review. - 2015. - 41, № 2. - P. 315-337.

5. Rudnytskyi O., N. Levchuk, O. Wolowyna, P. Shevchuk, and A. Kovbasuik Demography of a man-made human catastrophe: The case of massive famine in Ukraine 1932-1933 // Canadian Studies in Population. - 2015. - 42, № 1-2. - P. 53-81.

6. Вишневский $A$. Смертность в России: несостоявшаяся вторая эпидемиологическая революция // Демографическое обозрение. - 2014. - № 4. - С. 5-40.

7. Андреев Е.M. О связи реального и гипотетического поколений // Модели демографических связей. - М. : Статистика, 1972. - С. 14-39.

8. Shkolnikov V.M., Jdanov D.A., Andreev E.M., Vaupel J.W. Steep increase in best-practice cohort life expectancy // Population and Development Review. - 2011. - № 37 (3). - P. 419-434. 


\section{REFERENCES}

1. Shkolnikov, V.M. (2012). Chapter 7. Health Crises and Cohort Mortality. Mortality and causes of death in 20th-century Ukraine. Demographic Research Monographs. Meslé, F., Vallin, J. (Ed.);. Springer.

2. Wilmoth, J.R. (2005). On the relationship between period and cohort mortality. Demographic Research, Vol. 13, 11, 231-280 [in English].

3. Reher, D.S. (2011). Economic and social implications of the demographic transition. Demographic transition and its consequences. Ronald, D. Lee, David, S. Reher (Ed.). Vol. 37, 11-33 [in English].

4. Romaniuk, A., Gladun, O. (2015). Demographic trends in Ukraine: past, present and future. Population and Development Review, Vol. 41, 2, 315-337 [in English].

5. Rudnytskyi, O., Levchuk, N., Wolowyna, O., Shevchuk, P., \& Kovbasuik, A. (2015). Demography of a man-made human catastrophe: The case of massive famine in Ukraine 1932-1933. Canadian Studies in Population, Vol. 42, 1-2, 53-81 [in English].

6. Vishvevsky, A.G. (2014). Smertnost v Rossii : nesostoyavshayasia vtoraya epidemiologicheskaia revolutsia [Mortality in Russia : the second epidemiologic revolution that never was]. Demohrafycheskoe obozrenye - Demographic Review, 4, 5-40 [in Russian].

7. Andreev, E.M. (1972). O svyasi realnogo i gipoteticheskogo pokolenii [On the link between real and synthetic cohorts]. Modeli demographicheskikh svyasei - Models demographic relations. (p. 14-39). M. : Statistika [in Russian].

8. Shkolnikov, V.M., Jdanov, D.A., Andreev, E.M., \& Vaupel, J.W. (2011) Steep increase in best-practice cohort life expectancy. Population and Development Review, 37(3), 419-434 [in English].

Стаття надійшла до редакції журналу 30.01.2016. 